\title{
Modern approaches to the treatment of retrosternal goiter
}

\author{
V. V. Grubnik, R. S. Parfentiev, V. M. Kosovan, N. D. Parfentieva \\ Odessa National Medical University
}

\section{Сучасні підходи до лікування загруднинного зоба}

\author{
В. В. Грубнік, Р. С. Парфентьев, В. М. Косован, Н. Д. Парфентьева
}

Одеський національний медичний університет

\begin{abstract}
Objective. To analyze the results of treatment of patients with retrosternal goiter.

Materials and methods. During the period from 2010 to 2019, 62 patients with thoracic goiter were operated on, which was $6.2 \%$ of all patients operated in relation to goiter. There were 48 women (77.4\%) and 14 men (22.6\%). Age of patients varied from 21 to 87 years (average age -47 years). Computed tomography was mandatory in terms of research. The size of the sternal goiter and the degree of operative risk were determined by G. Mercante (2011).

Results. In 39 patients (1st group) the operation was performed by cervicotomy according to standard techniques. Video endoscopic support was used in 23 patients, thanks to which in 15 patients (group 2) it was able to cross all blood vessels with the help of an electro coagulator and isolate nerve structures and parathyroid glands. In 8 patients (group 3) there was a massive bleeding after attempts of finger dissection. They underwent tamponade and temporarily stopped bleeding. After that, a video endoscope was inserted into the wound and hemostasis was performed with the help of an electrocoagulation. Bleeding from the surgical wound, which required revision, was not observed. Temporary tracheostomy in the postoperative period was imposed in 3 patients, later it was closed. Hypocalcemia occurred in 12 (19.3\%) patients (in 11 it was transient). Transient paresis of the recurrent nerves was observed in 3 patients of the 1st, 2 of the 2 nd and 2 of the 3 rd groups. Permanent paresis of the recurrent nerve occurred in only 1 patient of the 3rd group. According to histological examination, 21 patients were diagnosed with cancer (19 - papillary, 2 - follicular). They subsequently underwent standard treatment for highly differentiated thyroid cancer. Conclusions. The use of cervical access with video endoscopic support during surgery for thoracic goiter avoids performing a sternotomy, reduces blood loss and operational trauma, improves the nerve structures and parathyroid glands identification, and reduces the duration of surgery. The use of modern methods of electrocoagulation significantly expands the capabilities of endoscopic techniques.
\end{abstract}

Keywords: thoracic goiter; video-assisted thyroidectomy.

Реферат

Мета. Проаналізувати результати лікування пацієнтів із загруднинним зобом.

Матеріали і методи. За період із 2010 по 2019 р. оперовано 62 пацієнти із загруднинним зобом, що становило 6,2\% від усіх пацієнтів, оперованих з приводу зоба. Жінок було 48 (77,4\%), чоловіків - 14 (22,6\%). Вік пацієнтів - від 21 до 87 років (середній вік - 47 років). У плані дослідження обов'язковою була комп'ютерна томографія. Величину загруднинного зоба та ступінь операційного ризику визначали за G. Mercante (2011).

Результати. У 39 пацієнтів (1-ша група) операція виконана цервікотомічним способом за стандартною технікою. У 23 пацієнтів використовували відеоендоскопічну підтримку, завдяки чому у 15 пацієнтів (2-га група) вдалося за допомогою електрокоагулятора перетнути всі судини і виділити нервові структури та прищитоподібні залози. У 8 пацієнтів (3-тя група) після спроб пальцевої дисекції виникла масивна кровотеча. У них виконана тампонада і тимчасово зупинена кровотеча. Після цього в рану ввели відеоендоскоп і за допомогою електрокоагулятора виконали гемостаз. Кровотечі з операційної рани, яка потребувала їі ревізії, не спостерігали. Тимчасову трахеостому в післяопераційному періоді накладено у 3 пацієнтів, пізніше вона була закрита. Гіпокальціємія виникла у 12 (19,3\%) пацієнтів (у 11 - транзиторна). Транзиторний парез поворотних нервів спостерігали у 3 пацієнтів 1-ї, у 2 - 2-ї і у 2 - 3-ї групи. Перманентний парез поворотного нерва виник тільки у 1 пацієнта 3-ї групи. За даними гістологічного дослідження у 21 пацієнта діагностовано рак (у 19 - папілярний, у 2 - фолікулярний). Їм у подальшому проведено стандартне лікування високодиференційованого раку щитоподібної залози.

Висновки. Використання шийного доступу з відеоендоскопічною підтримкою при оперативних втручаннях 3 приводу загруднинного зоба дозволяє уникнути виконання стернотомії, зменшити крововтрату і травматичність операції, поліпшити ідентифікацію нервових структур і прищитоподібних залоз, скоротити тривалість операції. Використання сучасних методів електрокоагуляції значно розширює можливості ендоскопічної техніки.

Ключові слова: загруднинний зоб; відеоасистована тиреоїдектомія.

Among all diseases of thyroid gland (thyroid, requiring surgical treatment, thoracic goiter occupies approximately $4-15 \%[1,2]$. As a rule, part of the goiter is located behind the upper sternum in anterior mediastinum. Most often, a similar location of the goiter is observed in people owing hypertensive constitutional body structure with a short neck.
At the same time, the phenomena of the compression syndrome are connected with finding of the volume formation in thorax which is limited by the bone structures (ribs, backbone, clavicles, sternum) may occur. Most often the compression by trachea displaced is observed, less often -by the bronchi. Treatment of thoracic goiter is only surgical. Due 
to the danger of respiratory complications with compression of the trachea, surgery is vital $[2,3]$.

The study purpose was to investigate the features of operative intervention for thoracic goiter, to analyze the results of the treatment, and to determine the rational surgical approach.

\section{Materials and methods}

In the surgical clinic on the base of the Odessa Regional Clinical Hospital during the period 2010 - 2019 yrs, 62 patients with thoracic goiter were treated, what have constituted $6.2 \%$ of all patients operated on for goiter. The examination plan, in addition to standard general clinical studies, have included the determination of thyroid hormone levels in the blood, ultrasound (US) of the thyroid gland and vocal cords, ultrasound of the neck vessels, the chest X-ray, computed tomography (CT) of the neck and mediastinum (if necessary - with contrast), indirect laryngoscopy, electrocardiographic examination, examination of the external respiration function. The majority of patients were women - 48 (77.4\%). Age of patients - from 21 to 87 years (average age -47 yrs old). There were 51 (82.2\%) patients diagnosed with nodular / multinodular, and 9 (14.5\%) - nodular (or multinodular) toxic goiter.

In most patients, retrosternal goiter developed as a socalled secondary thoracic goiter, which was characterized by a long period of development and gradual displacement of the thyroid gland beyond the sternum. Primary sternal goiter is rare. It is caused by ectopia of thyroid tissue that is not associated with conventional cervical thyroid disease. This goiter was diagnosed in 3 patients (one woman and two men).

Initially, 38 (61.3\%) patients sought medical attention due to clinical manifestations of goiter. In most of them, the diagnosis was preceded by a fairly long examination and treatment of clinical syndromes, which have had manifested thoracic goiter, but were treated as various diseases of the respiratory and cardiovascular systems. In other patients, owing corresponding complaints, the disease was discovered accidentally during radioscopy, or CT, or ultrasound, and by more careful history taking. Cervical-thoracic goiter was characterized by signs of the compression syndrome with specific complaints, clinical data and instrumental confirmation. Symptoms of compression of varying degrees were found in 66\% of thems: 39 (62.9\%) patients complained of a "feeling of compression" in the neck and upper chest, what was exacerbated by changes in the head position or eating of the dense food. Periodic cough was observed in 23 (37.1\%) patients, especially in the supine position or while squeezing the neck with clothing. Violations of phonation of varying degrees were observed in 15 (24.2\%) patients. Among the external (objective) clinical manifestations, symptoms of the neck deformity and varicose veins prevailed - the syndrome of "superior vena cava" of various degrees of manifestation was present in 5 (8.1\%) patients.

Most patients had either euthyroidism or drug-compensated hypothyroidism. Hyperthyroidism was found in
4 (6.5\%) patients, which required prescription of thyrostatics in preoperative period.

The first objective confirmation of cervical goiter was given by the cervical ultrasound daya. A variable frequency sensor and a polypositional study were used. Dopplerography of the neck vessels was performed, the mobility of the vocal cords, the degree of displacement of trachea relative to the axis of the neck, the possibility of the lower thyroidal poles visualization and the degree of their mobility were assessed. The volume of the thyroid gland varied from 40 to $108 \mathrm{~cm}^{3}$. Ultrasound of the goiter diagnosis was confirmed in $76 \%$ of patients. CT (both with contrast enhancement and without it) was performed in all patients to clarify the location, the degree of spread of the goiter (relative to tracheal bifurcation and aortic arch pressure impact), possible invasion of surrounding structures, the degree of tracheal displacement in the chest ( 55 patients - deviation of trachea, in 10 - change in its lumen), what is not available on ultrasound. If necessary, isotopic scintigraphy with $\mathrm{Tc}^{99}$ was also used.

The size of thoracic goiter according to the CT classification of G. Mercante [4] was determoned, with consideration of three spatial vectors in the tumor distribution: cranio-caudal, anteroposterior, latero-lateral.

Cranio-caudal distribution have included three classes: class 1 - the lower edge of the goiter between the upper thoracic aperture above the aortic arch, class $2-$ at the level of the aortic arch, class 3 - below the aortic arch.

Anterior-posterior distribution have included the ratio of the goiter, the aortic arch with its branches and the trachea with the bronchi. There were three types: type A most of the goiter is located between the sternum and aorta; type $\mathrm{B}$ - most of the goiter is between the aorta and trachea (and paratracheally); type $\mathrm{C}$ - most of the goiter is located retrotracheally. Combination of types $\mathrm{A}$ and $\mathrm{B}$ is common.

According to this classification, the distribution of patients was as follows. Cranio-caudal distribution: class 1 39 , class $2-21$, class $3-2$; front-rear: type A - 35, type B 18, type C - 9; latero-lateral: monolateral - 46, bilateral - 16 .

The degree of operative risk was considered high in the presence of the following factors: goiter class 3; recurrent process, simultaneously types A and B or A, B and C; goiter, consisting of several parts (similar to a bunch of grapes), the shape of the goiter in the form of an iceberg or cone (ie, extending downward); goiter fused with the parietal pleura. Goiters reaching the aortic arch and having oval or tubular shape, goiter with minimal spread to the posterior mediastinum and retrotracheally were considered owing a medium operative risk. The low risk goiter have spreaded behind the collarbone only.

\section{Results}

Intraoperatively we have had the opportunity at any time to proceed with sternotomy in case of bleeding and other complications. The access of choice was cervicotomy, according to Kocher, with unilateral or bilateral intersection 
of the pretracheal muscles. However, after mobilization of the upper pole and ligation of the upper thyroid vessels, it was possible to dislocate the lower pole of the thyroid gland with subsequent ligation of the lower thyroid vessels. The middle part of the thyroid gland was then separated from the trachea with isolation and visualization of the recurrent nerve and thyroid gland, followed by sectioning of the Berry ligament. If necessary, the second part of the goiter was removed as well. The operation was completed by hemostasis in the area of the thyroid bed in the mediastinum. According to this scheme, the operation was performed in 39 patients (1st group). In the remaining 23 patients we failed to dislocate the goiter in the wound. Among them were patients with goiter of classes 2 and 3 , type $B$ and $A+B$, as well as goiter in the form of iceberg or cone. In them, with the help of a spatula, the gland was pushed back and up and a 5- or 10-millimeter video endoscope was inserted into the mediastinum. With the help of electrocoagulator LigaSure under endoscopic control the vessels leading to the lower pole of the thyroid gland were divided. Then the middle part of the gland was isolated. The recurrent nerve and thyroid gland were also isolated and identified under the control of endoscope, which made it possible to avoid their damage with high probability. According to this scheme, the operation was performed in 15 patients (group 2). In 8 patients (3rd group) after attempts of the finger dissection and removal of a node in a wound there a massive bleeding have occurred. However, we were in no hurry to perform a sternotomy. With the help of a tight tamponade of the mediastinum, it was possible to achieve a temporary cessation of bleeding, after which thoracoscope was inserted, giving possibility to examine the sternum and mediastinum methodically and securely. The source of bleeding was verified and arrested with Ligasure electrocoagulator. In all patients the source of bleeding were the branches of the thyroid arteries or venous plexus. The central vessels were not damaged.

The operation was completed by draining of the mediastinum with a Penrose-type drainage. In case of severe bleeding a hemostatic sponge was used together with tamponade of the wound with gauze tourniquet, which was removed the next day or after 2 days. This method of hemostasis was performed only in 8 patients of the 1st group. While $53 \mathrm{pa}-$ tients required removal of the entire thyroid gland, the other underwent subtotal thyroidectomy.

The average duration of operative intervention in $\mathrm{pa}$ tients of the 1st group was $(81.3 \pm 8.6) \mathrm{min}$, while in the 2nd group - (115.2 \pm 10.3$) \mathrm{min}$, and in the 3rd group $(123 \pm 11.7) \mathrm{min}$.

The average volume of blood loss in patients of the $1 \mathrm{st}$ group was $(85 \pm 13) \mathrm{ml}$, in the 2nd group - $(154 \pm 14) \mathrm{ml}$, and in the 3rd group - $(330 \pm 19) \mathrm{ml}$.

Bleeding from the surgical wound, which required its revision, occurred in 3 patients of the 1st group. No postoperative bleeding was observed in patients of the 2 nd and 3 rd groups.

The need for tracheostomy in postoperative period was noted in 3 patients (in $2-3$ groups and in $1-2$ groups).
In 2 patients tracheostomy was closed 1 mo after surgery. In 1 patient in 4 mo postoperatively chordotomy was performesd before tracheostomy was also closed.

Hypocalcemia in postoperative period have occurred in 12 (19.3\%) patients (11 - transient, 1 - permanent).

Injury of the recurrent nerve was observed in 3 patients of the 1 st, 2 - of the 2 nd and 2 - in the 3 rd group. The paresis of the recurrent nerve was transient with subsequent reduction of symptoms within $2-4$ mo. The permanent nature of the paresis of the recurrent nerve was observed only in 1 patient of the 3rd group.

According to histological examination, 21 patients were diagnosed with cancer (19 - papillary, 2 - follicular). Combination of multinodular goiter and thyroiditis was detected during histological examination in other patients. All patients diagnosed with cancer underwent total thyroidectomy with removal of pretracheal lymph nodes (ie, the central lymph node dissection). Later they received a course of radioiodine therapy.

\section{Discussion}

Thoracic goiter is a rather complex surgical problem. About 2.5 to $20 \%$ of all thyroidectomies are performed for thoracic goiter $[5,6]$. In our study, this figure was $6.2 \%$. Thoracic goiter grows rather slowly, so most often operations are performed on patients aged $56-72$ yrs old [7].

In our series of observations the mean age of patients was $(47 \pm 5.5)$ yrs old. Most often the women are operated on for goiter. According to various studies, this figure ranges from 87 to $94 \%[8,9]$. Among the patients we have studied, the women have accounted for $77.4 \%$.

Clinical manifestations of thoracic goiter are characterized by symptoms of respiratory disorders due to compression and displacement of the trachea. In our study these symptoms were expressed in 66\% of patients. Dysphagia, associated with esophageal compression, may occur in 5 $20 \%$ of patients $[10,11]$. In our study, symptoms of swallowing disorders were present in $9 \%$ of patients. Hoarseness of the voice due to compression of the recurrent nerve or sympathetic trunks of the cervical-thoracic or cervical-shoulder nerves [12] may indicate not only the large size of thoracic goiter, but the malignancy of the process as well. Disturbances of tone and hoarseness of voice were observed in $24,2 \%$ of the patients.

The frequency of symptoms of venous compression, according to the literature data, constitutes $3-19 \%[10,12]$. This syndrome was expressed in $4 \%$ of the patients examined.

Most often, ultrasound scanning is used as a method of the thyroid examination, but more informative is CT, which allows to determine the size of the thoracic goiter, its relationship within the mediastinum, and with large vessels especially [13 - 15]. Based on the CT data, the classification of G. Mercante [4] was developed, which allows to specify the location and size of the thoracic goiter.

The question of optimal surgical access is one of the main ones in the thoracic goiter surgery. According to opinion of 
most researchers, thoracic goiter can be removed through cervical access [16 - 19]. Large thoracic goiter, which has the appearance of an iceberg, as well as a recurrent one constitute indications for application of sternotomy or thoracotomy.

By our observations, it is also possible to remove the thoracic goiter through cervical approach and dissection in all patients successfully, what have reduced the operative trauma significantly. The first stage of the operation was the selection of the upper lobe of the thyroid gland with division of upper vessels. Then ligated and crossed the middle thyroid vein. It should be noted that in the vast majority of operated patients we used the "LigaSure" device, which have allowed to "brew" and cross the vessels reliably. After crossing the vessels, it was possible to carefully "dislocate" the thoracic part of the thyroid gland outwards, what simplified the further course of the operation greatly.

At the same time, such a recept is not always possible in this type of surgery. While technical difficulties present, we widely used video-assisted support. Because with the help of modern video endoscopic equipment, inserted into the upper mediastinum, it was possible to inspect the surface of the thoracic thyroid gland thoroughly, to identify vessels and nerves and to process them securely, using "LigaSure". This technique was used by us in $37 \%$ of operated patients.

It should be noted, that the magnification and clarity of the image of the thoracic thyroid gland and upper mediastinum allows surgeon-operator to navigate in the anatomy of the upper mediastinum and to perform operations quite safely, without the use of sternotomy. This tactic have allowed us to avoid the most dangerous intraoperative complication massive bleeding, which is observed in $4.2-14.3 \%$ of patients [3]. The maximum blood loss in our study series was $350 \mathrm{ml}$, and the average intraoperative blood loss - $(128 \pm 22.5) \mathrm{ml}$.

Mortality in the thoracic goiter surgery can range from $5.7 \%[3,22]$ to $15.3 \%$ [23]. In most patients who died, a sternotomy was performed [3, 23].

After a series of operations for thoracic goiter, performed by us, there was no mortality, despite a rather heavy contingent of the patients operated. The use of cervical access in all patients have permitted to avoid such a complication as pneumothorax, which is also described in the literature [3].

Hypocalcemia in postoperative period can be observed with a frequency of up to $33 \%[3,24,25]$. In our observations transient hypocalcemia have occurred in 12 (19.3\%) patients only. We also noted, that the use of modern video endoscopic equipment allows to better identify the thyroid gland and to damage them less often.

A specific complication of all thyroid surgery is the recurrent nerve damage with subsequent change in the voice due to it. Damage to recurrent nerves is observed in 2.7 $14.3 \%$ of patients with thoracic goiter $[3,8,26]$. Fortunately, in most patients, the voice recovers over time.

In our observations voice disorders were noted in 7 (11.3\%) patients, but in almost all of them the voice was have restored almost completely. Only 1 (1.6\%) patient had this persistent disorder.
To reduce the frequency of this complication, it is important to improve surgical techniques and visualization during the operation on recurrent nerve with precision dissection accomplishing during manipulations on the thyroid capsule.

Numerous studies have shown, that the introduction of neuro-monitoring does not always prevents the damage to recurrent nerve [3, $27-30]$.

We have adhered to generally accepted principles regarding the scope of the goiter surgery. In the presence of malignancy all patients underwent total thyroidectomy. With the large size of both thyroid lobes, the entire gland was also removed, taking into account that surgery for recurrent thoracic goiter is always associated with great technical difficulties. If only one part of the thyroid gland was significantly enlarged and located thoracically, we removed only this part, in some patients - with resection of the second part. There were only 9 such patients.

Thus, sternal goiter is a rather complex surgical problem. Patients with thoracic goiter should be operated on in special centers that have extensive experience of thyroid surgery.

In the vast majority of patients, sternal goiter can be removed through cervical access and dissection. Application of video-assisted support in case of the intraoperative exposure difficulties allows to avoid serious complications and to escape necessity of sternotomy performance.

With good technical support, the frequency of specific complications in operations for thoracic goiter does not exceed the frequency of complications in standard thyroid surgery.

\section{Conclusions}

The use of cervical access with video support during surgery for thoracic goiter avoids sternotomy, reduces intraoperative blood loss and trauma, improves identification of the nerve structures and thyroid gland, reduces the operation duration. Application of modern methods of electrocoagulation expands the capabilities of endoscopic techniques significantly.

Financing. The authors' own funds were used.

Contribution of each participant. Grubnik VV - concept and design of research, analysis of the received data, formation of conclusions; Parfentiev RS - collection and processing of materials, analysis of the received data, writing of the text, registration to the press; Kosovan VM - collection and processing of materials, analysis of the obtained data, formation of conclusions; Parfentieva ND - collection and processing of materials, analysis of the obtained data, registration for printing.

Conflict of interest. The authors state that they have no conflict of interest.

\section{References}

1. Brenet E, Dubernard X, Mérol JC, Louges MA, Labrousse M, Makeieff M. Assessment and management of cervico-mediastinal goiter. Eur Ann Otorhinolaryngol Head Neck Dis. 2017 Dec;134(6):409- 
13. doi: 10.1016/j.anorl.2017.06.001. Epub 2017 Jun 28. PMID: 28668317.

2. Khan MN, Goljo E, Owen R, Park RC, Yao M, Miles BA. Retrosternal Goiter: 30-Day Morbidity and Mortality in the Transcervical and Transthoracic Approaches. Otolaryngol Head Neck Surg. 2016 Oct;155(4):568-74. doi: 10.1177/0194599816649583. Epub 2016 May 24. PMID: 27221572.

3. Simó R, Nixon IJ, Vander Poorten V, Quer M, Shaha AR, Sanabria A, et al. Surgical management of intrathoracic goitres. Eur Arch Otorhinolaryngol. 2019 Feb;276(2):305-14. doi: 10.1007/s00405018-5213-z. Epub 2018 Nov 30. PMID: 30506185.

4. Mercante G, Gabrielli E, Pedroni C, Formisano D, Bertolini L, Nicoli F, et al. CT cross-sectional imaging classification system for substernal goiter based on risk factors for an extracervical surgical approach. Head Neck. 2011 Jun;33(6):792-9. doi: 10.1002/ hed.21539. Epub 2010 Aug 24. PMID: 20737483.

5. White ML, Doherty GM, Gauger PG. Evidence-based surgical management of substernal goiter. World J Surg. 2008 Jul;32(7):1285300. doi: 10.1007/s00268-008-9466-3. PMID: 18266028.

6. Shaha AR. Substernal goiter: what is in a definition? Surgery. 2010 Feb;147(2):239-40. doi: 10.1016/j.surg.2009.10.066. PMID: 20109623.

7. Singh B, Lucente FE, Shaha AR. Substernal goiter: a clinical review. Am J Otolaryngol. 1994 Nov-Dec;15(6):409-16. doi: 10.1016/0196-0709(94)90081-7. PMID: 7872476.

8. Ríos A, Rodríguez JM, Galindo PJ, Torres J, Canteras M, Balsalobre MD, et al. Results of surgical treatment in multinodular goiter with an intrathoracic component. Surg Today. 2008;38(6):48794. doi: 10.1007/s00595-006-3673-z. Epub 2008 May 31. PMID: 18516526.

9. Benbakh M, Abou-elfadl M, Rouadi S, Abada RL, Roubal M, Mahtar M. Substernal goiter: Experience with 50 cases. Eur Ann Otorhinolaryngol Head Neck Dis. 2016 Feb;133(1):19-22. doi: 10.1016/j. anorl.2015.09.007. Epub 2015 Oct 29. PMID: 26520480.

10. Landerholm K, Järhult J. Should asymptomatic retrosternal goitre be left untreated? A prospective single-centre study. Scand J Surg. 2015 Jun;104(2):92-5. doi: 10.1177/1457496914523411. Epub 2014 Apr 23. PMID: 24759378.

11. Chen AY, Bernet VJ, Carty SE, Davies TF, Ganly I, Inabnet WB 3rd, et al. American Thyroid Association statement on optimal surgical management of goiter. Thyroid. 2014 Feb;24(2):181-9. doi: 10.1089/thy.2013.0291. Epub 2014 Jan 20. PMID: 24295043.

12. Marcelino M, Nobre E, Conceição J, Lopes L, Vilar H, de Castro JJ. Superior vena cava syndrome and substernal goiter. Thyroid. 2010 Feb;20(2):235-6. doi: 10.1089/thy.2009.0188. PMID: 20151836.

13. Ayache S, Mardyla N, Tramier B, Strunski V. Signes cliniques et corrélations radiocliniques dans une série de 117 goitres cervicothoraciques [Clinical signs and correlation with radiological extent in a series of 117 retrosternal goitre]. Rev Laryngol Otol Rhinol (Bord). 2006;127(4):229-37. French. PMID: 17315787.

14. Anders HJ. Compression syndromes caused by substernal goitres. Postgrad Med J. 1998 Jun;74(872):327-9. doi: 10.1136/ pgmj.74.872.327. PMID: 9799884; PMCID: PMC2360941.

15. Kabala JE. Computed tomography and magnetic resonance imaging in diseases of the thyroid and parathyroid. Eur J Radiol. 2008 Jun;66(3):480-92. doi: 10.1016/j.ejrad.2008.03.030. Epub 2008 May 27. PMID: 18502599.

16. Zainine R, El Aoud C, Bachraoui R, Beltaief N, Sahtout S, Besbes G. Les goîtres plongeants : à propos de 43 cas [The plunging goiter : about 43 cases]. Tunis Med. 2011 Nov;89(11):860-5. French. PMID: 22179923.
17. Raffaelli M, De Crea C, Ronti S, Bellantone R, Lombardi CP. Substernal goiters: incidence, surgical approach, and complications in a tertiary care referral center. Head Neck. 2011 Oct;33(10):1420 5. doi: 10.1002/hed.21617. Epub 2010 Nov 10. PMID: 21928414.

18. Makeieff M, Marlier F, Khudjadze M, Garrel R, Crampette L, Guerrier B. Les goitres plongeants. A propos de 212 cas [Substernal goiter. Report of 212 cases]. Ann Chir. 2000 Jan;125(1):18-25. French. PMID: 10921180.

19. Shai SE, Chen CY, Hsu CP, Hsia JY, Yang SS, Chuang CY, et al. Surgical management of substernal goiter. J Formos Med Assoc. 2000 Nov;99(11):827-32. PMID: 11155771.

20. Hanson MA, Shaha AR, Wu JX. Surgical approach to the substernal goiter. Best Pract Res Clin Endocrinol Metab. 2019 Aug;33(4):101312. doi: 10.1016/j.beem.2019.101312. Epub 2019 Aug 22. PMID: 31477522; PMCID: PMC6815725.

21. Flati G, De Giacomo T, Porowska B, Flati D, Gaj F, Talarico C, et al. Surgical management of substernal goitres. When is sternotomy inevitable? Clin Ter. 2005 Sep-Oct;156(5):191-5. PMID: 16382967.

22. Sancho JJ, Kraimps JL, Sanchez-Blanco JM, Larrad A, Rodríguez JM, Gil P, et al. Increased mortality and morbidity associated with thyroidectomy for intrathoracic goiters reaching the carina tracheae. Arch Surg. 2006 Jan;141(1):82-5. doi: 10.1001/archsurg.141.1.82. PMID: 16415416.

23. Di Crescenzo V, Vitale M, Valvano L, Napolitano F, Vatrella A, Zeppa P, et al. Surgical management of cervico-mediastinal goiters: Our experience and review of the literature. Int J Surg. 2016 Apr;28 Suppl 1:S47-53. doi: 10.1016/j.ijsu.2015.12.048. Epub 2015 Dec 23. PMID: 26721191.

24. Edafe O, Antakia R, Laskar N, Uttley L, Balasubramanian SP. Systematic review and meta-analysis of predictors of post-thyroidectomy hypocalcaemia. Br J Surg. 2014 Mar;101(4):307-20. doi: 10.1002/bjs.9384. Epub 2014 Jan 9. PMID: 24402815.

25. Testini M, Gurrado A, Avenia N, Bellantone R, Biondi A, Brazzarola $\mathrm{P}$, et a. Does mediastinal extension of the goiter increase morbidity of total thyroidectomy? A multicenter study of 19,662 patients. Ann Surg Oncol. 2011 Aug;18(8):2251-9. doi: 10.1245/s10434011-1596-4. Epub 2011 Feb 19. PMID: 21336513.

26. Jeannon JP, Orabi AA, Bruch GA, Abdalsalam HA, Simo R. Diagnosis of recurrent laryngeal nerve palsy after thyroidectomy: a systematic review. Int J Clin Pract. 2009 Apr;63(4):624-9. doi: 10.1111/j.1742-1241.2008.01875.x. PMID: 19335706.

27. Shindo M, Chheda NN. Incidence of vocal cord paralysis with and without recurrent laryngeal nerve monitoring during thyroidectomy. Arch Otolaryngol Head Neck Surg. 2007 May;133(5):481-5. doi: 10.1001/archotol.133.5.481. PMID: 17520762.

28. Dralle H, Sekulla C, Haerting J, Timmermann W, Neumann HJ, Kruse E, et al. Risk factors of paralysis and functional outcome after recurrent laryngeal nerve monitoring in thyroid surgery. Surgery. 2004 Dec;136(6):1310-22. doi: 10.1016/j.surg.2004.07.018. PMID: 15657592.

29. Barczyński M, Konturek A, Cichoń S. Randomized clinical trial of visualization versus neuromonitoring of recurrent laryngeal nerves during thyroidectomy. Br J Surg. 2009 Mar;96(3):240-6. doi: 10.1002/bjs.6417. PMID: 19177420.

30. Higgins TS, Gupta R, Ketcham AS, Sataloff RT, Wadsworth JT, Sinacori JT. Recurrent laryngeal nerve monitoring versus identification alone on post-thyroidectomy true vocal fold palsy: a metaanalysis. Laryngoscope. 2011 May;121(5):1009-17. doi: 10.1002/ lary.21578. PMID: 21520117.

Received: 25.12.2020 